\title{
The antioxidant properties and $\alpha$-amylase inhibition activities of polyphyto mixture with honey formulations
}

\author{
Rashidi, W.N.A.S.W.M., *Muhammad, N., Abdullah, N., Talip, B.A. and Bahrin, N. \\ Faculty of Applied Sciences and Technology, University Tun Hussein Onn Malaysia, Pagoh Educational \\ Hub, Km 1, Jalan Panchor, 84000 Muar, Johor, Malaysia.
}

\section{Article history:}

Received: 31 May 2020

Received in revised form: 11

July 2020

Accepted: 29 July 2020

Available Online: 22

September 2020

Keywords:

Antioxidant,

$\alpha$-amylase,

Interaction effect,

Polyphyto

DOI:

https://doi.org/10.26656/fr.2017.4(6).260

\begin{abstract}
Ficus carica, Orthosiphon stamineus, Ficus deltoidea and Trigona honey are known for their high antioxidant amount. In this research, these plants and honey were used to study their interactions in terms of the antioxidant properties and the inhibition of $\alpha$-amylase enzyme. These plants samples were chosen as they are usually used in traditional medicine to treat diabetes. Therefore, the objectives of this study are to measure the antioxidant activity as well as the $\alpha$-amylase enzyme inhibition properties of the polyphyto formulations and Trigona honey. Simplex Centroid Mixture Design (SCMD) was used to design the formulations. In this experiment, the highest $(p<0.05)$ antioxidant content for 2,2-diphenyl-1-picrylhydrazyl (DPPH) assay was a formulation of $100 \%$ Trigona honey $(90.09 \%)$. Meanwhile, a mixture of $50 \% \mathrm{~F}$. carica $-50 \%$ O. stamineus and $50 \%$ O. stamineus $-50 \%$ Trigona honey yield the highest $(p<0.05)$ total phenolic content (TPC) value (133.77 and $133.17 \mu \mathrm{g} / \mathrm{mL}$, respectively), which indicated a synergistic interaction effect. However, for the measurement of ferric reduction antioxidant potential (FRAP), the formulation of $100 \%$ O. stamineus and $100 \% \mathrm{~F}$. deltoidea exhibits the highest $(p<0.05)$ value $(148.95$ and $148.78 \mu \mathrm{g} / \mathrm{mL}$, respectively). In terms of enzyme inhibition, $F$. deltoidea showed the highest inhibition activity for $\alpha$-amylase (8.826\%). In conclusion, different percentages of $F$. carica, $O$. stamineus, $F$. deltoidea and Trigona honey have different interaction effects on the antioxidant activity and $\alpha$-amylase inhibition depending on the amount of each factor.
\end{abstract}

\section{Introduction}

People nowadays tend to find alternative medicine instead of only depending on medication prescribed by the doctors or pharmacists. Therefore, indicates a significant increase in sales of herbal supplements due to its numerous health benefits (Rashidi et al., 2019). By years, a lot of researches has been done on finding the plants that may help to reduce or treat diabetes as diabetes is known as the most common global disease where it affects 200 million individual and around 300 million people are at risk by approximate (McCune and Johns, 2002). The alternatives of using plants as substitutes for chemical drugs is due to the research on the bioavailability presence in each plant. Upon generations, $F$. carica has been said to have abundant of health benefits to human as mentioned in the Holy Qur'an (Marwat et al., 2011).

One of the causes of diabetes is the reduced plasma antioxidant level (Facchini et al., 2000). Antioxidants are mostly obtained from plants and herbs as they may prevent the development of the disease (Thompson and Godin, 1995; McCune and Johns, 2002). According to Kelble (2005), a decreasing amount of plasma antioxidant level increase the induction of the vascular disease seen in type II diabetes. Inhibition activity of $\alpha$ amylase enzyme can also stunt glucose uptake by the body as they function in promoting the uptake of glucose in the body.

$F$. carica, O. stamineus and F. deltoidea are the plants used in this experiment. The previous study reported that $F$. deltoidea may reduce the blood glucose level due to enhancement of glucose uptake in muscle and reduction of hepatic gluconeogenesis (Adam et al., 2007). Plants and herbs formulation are regularly reckoned to have lesser toxicity and does not contribute to any synthetic medicine's side effects (Malviya et al., 2010). Trigona honey was chosen to be added as it has strong antioxidant activities (Yazan et al., 2016). 
Antioxidant compounds such as organic acids, carotenoids, phenolic and vitamin E may inhibit the oxidative mechanisms that will eventually cause to degenerative illnesses (du Toit et al., 2001). The purpose of determining the total phenolic content of the formulation is to understand the relationship of the phenolic content to the antioxidant and anti-diabetic properties of the formulation. Therefore, the objectives of this study were to measure the antioxidant and $\alpha$ amylase enzyme inhibition properties of polyherbal formulations and Trigona honey.

\section{Materials and methods}

\subsection{Chemicals and instruments}

2, 2-Diphenyl-1-picrylhydrazyl (DPPH), methanol, Folin-Ciocalteu reagent, sodium carbonate, acetate buffer, glacial acetic acid and TPTZ (2, 4, 6-tripyridyl-striazine) were purchased from Merck, Germany. 3, 5Dinitrosalicylic acid were bought from QReC, Asia while $\alpha$-amylase were bought from Sigma-Aldrich, USA. The instrument used was UV-Vis spectrophotometer (T60u, PG Instrument, USA) located in Food Analysis Laboratory, UTHM.

\subsection{Preparation of leaves extracts}

$F$. carica dried leaves were bought from Formeniaga Company in Selangor while $O$. stamineus and $F$. deltoidea dried leaves were bought from Ethno Resources, Sg. Buloh. All of these plants were ground before being extracted to reduce the size. Each plant has a different extraction method based on the optimum yield of extraction for each plant. F. carica was extracted with maceration of $70 \%$ ethanol as applied from Vongsak et al. (2013). A total of $165 \mathrm{~g}$ of $F$. carica dried ground leaves were weighed using the weighing machine model TX3202L, Shimadzu, Japan and macerated with 70\% ethanol $(1: 40, \mathrm{w} / \mathrm{v})$ for $72 \mathrm{hrs}$ at room temperature. Next, it was agitated on a shaker with a speed of $70 \mathrm{rpm}$ and the extract was filtered using Whatman No. 1 filter paper and the marc was re-macerated in the same solvent until the extraction was exhausted. The liquid extract was left in the fume hood at room temperature until the ethanol was removed completely. It was left refrigerated at $4{ }^{\circ} \mathrm{C}$ until further use.

O. stamineus was extracted using soxhlet method as it gives comparatively high yield percentage of extract compared to other methods. A total of $5 \mathrm{~g}$ of the dried leaves powder was extracted in $60 \%$ aqueous ethanol (w/ $v)$, heated according to the solvent's boiling point ( $>78^{\circ}$ C) for $2 \mathrm{hrs}$. All extracts were filtered and concentrated under a fume hood at room temperature. The extracts were kept refrigerated at $4^{\circ} \mathrm{C}$ until further use (Mansor et al., 2016). F. deltoidea was extracted with the method outlined by Hasham et al. (2013) with a little bit of modification. A total of $30 \mathrm{~g} \mathrm{~F}$. deltoidea leaves were extracted with $0.48 \mathrm{~L}$ of hot boiling water for 20 mins. Whatman No. 1 filter paper was used to filter the solid parts and the liquid was kept refrigerated until further use.

\subsection{Development of plants formulation}

The formulations are made up of different percentages of mixture generated by a statistical software program, Design Expert® 6.0.4. (Stat-Ease, United States) and it was standardized at $20 \mathrm{~g} / 100 \mathrm{~mL}(100 \% \mathrm{w} /$ v) of the formulation. Four components in the mixtures, including the extracts of $F$. carica, O. stamineus, $F$. deltoidea and Trigona honey were selected as causal factors. The interaction effects of phytochemicals in antioxidant and $\alpha$-amylase inhibitory activity were determined by comparing the experimental result with the predicted value according to the method of PalafoxCarlos et al. (2012), with slight modification. The predicted value is the addition of the individual values of the samples according to each proportion in the formulation.

\subsection{DPPH radical scavenging assay}

Radical scavenging activity of this formulation was determined spectrophotometrically by using the 2, 2diphenyl-1-picrylhydrazyl (DPPH) assay. The DPPH is basically reduced due to the donation of hydrogen from the antioxidant compound when the DPPH reacts with it. The colour changes were measured on a UV-Vis spectrophotometer at $515 \mathrm{~nm}$. In this method, the DPPH was diluted in methanol to a concentration of $6 \times 10^{-5} \mathrm{M}$ (2.37 mg per $100 \mathrm{~mL}$ ) (Miliauskas et al., 2004). Three (3) $\mathrm{mL}$ of DPPH solution was incorporated with $77 \mu \mathrm{l}$ of extract in cuvettes and kept in dark condition for 15 mins at room temperature. The blank sample was prepared to contain the exact volume of methanol and DPPH, then its absorbance value was measured. The experiment was done in triplicate. The calculation of the percentage inhibition can be expressed using the equation shown:

$$
\% \text { inhibition }=\left[\frac{(\mathrm{x}-\mathrm{y})}{\mathrm{x}}\right] \times 100
$$

Where $\mathrm{x}=$ the blank absorption at $\mathrm{t}=0 \mathrm{~min}$; and $\mathrm{y}=$ the extract absorption at the 15 th mins.

\subsection{FRAP assay}

Ferric reduction antioxidant potential (FRAP) assay was done conferring to Benzie and Strain (1996) with minor modification. Reagents used were $300 \mathrm{mmol} / \mathrm{L}$ acetate buffer, $\mathrm{pH} 3.6\left(3.1 \mathrm{~g} \mathrm{C}_{3} \mathrm{H}_{3} \mathrm{NaO} \cdot 3 \mathrm{H}_{2} \mathrm{O}\right)$, and 16 $\mathrm{mL} \mathrm{C}_{2} \mathrm{H}_{4} \mathrm{O}_{2}$ (glacial acetic acid) in $1 \mathrm{~L}$ of buffer solution; $10 \mathrm{mmol} / \mathrm{L} \mathrm{2}, 4$, 6-tripyridyl-s-triazine (TPTZ) in 40 $\mathrm{mmol} / \mathrm{L} \mathrm{HCl} ; 20 \mathrm{mmol} / \mathrm{L} \mathrm{FeCl}_{3} \cdot 6 \mathrm{H}_{2} \mathrm{O}$. Working FRAP 
reagent was prepared as required by mixing $25 \mathrm{~mL}$ acetate buffer, $2.5 \mathrm{~mL}$ TPTZ solution and $2.5 \mathrm{~mL}$ $\mathrm{FeCl}_{3} \cdot 6 \mathrm{H}_{2} \mathrm{O}$ solution. Warmed $\left(37^{\circ} \mathrm{C}\right)$ FRAP reagent (3 $\mathrm{mL}$ ) and its absorbance was read at $593 \mathrm{~nm}$. About 100 $\mu \mathrm{L}$ of the sample was then incorporated with $300 \mu \mathrm{L}$ $\mathrm{H}_{2} \mathrm{O}$. Absorbance reading was measured after 4 mins. The experiment was done in triplicate. The absorbance change between the final value and the blank absorption value was quantified for every single formulation and compared with a standard curve. The standard curve was made by using different concentration of the reagents as shown in Table 1. The absorbance value was read at 593 $\mathrm{nm}$ after exposed in the dark for 30 mins.

Table 1. Concentration reagents in making a standard curve for FRAP

\begin{tabular}{lcccccccc}
\hline Reagent & 1 & 2 & 3 & 4 & 5 & 6 & 7 & 8 \\
\hline $\mathrm{H}_{2} \mathrm{O}(\mu \mathrm{L})$ & 1000 & 985 & 970 & 940 & 880 & 820 & 760 & 700 \\
$\begin{array}{l}\text { 1mM Std } \\
(\mu \mathrm{L})\end{array}$ & 0 & 15 & 30 & 60 & 120 & 180 & 240 & 300 \\
$\begin{array}{l}\text { FRAP } \\
(\mathrm{mL})\end{array}$ & 2 & 2 & 2 & 2 & 2 & 2 & 2 & 2 \\
$\begin{array}{l}\text { Std Conc } \\
(\mu \mathrm{M})\end{array}$ & 0 & 5 & 10 & 20 & 40 & 60 & 80 & 100 \\
\hline
\end{tabular}

\subsection{Total phenolic content (TPC)}

The total phenolic content (TPC) assay was experimented according to Miliaukas et al. (2004). The reference sample was made by taking $1 \mathrm{~mL}$ gallic acid solutions aliquots with the concentration of 10, 20, 40 and $80 \mu \mathrm{g} / \mathrm{mL}$ and incorporated with $5 \mathrm{~mL}$ of FolinCiocalteu reagent (diluted ten-fold) added with $4 \mathrm{~mL}$ (75 $\mathrm{g} / \mathrm{L}$ ) sodium carbonate. Absorbance reading was taken at $20^{\circ} \mathrm{C}$ at $750 \mathrm{~nm}$ after 30 mins to determine its calibration curve. About $100 \mu \mathrm{L}$ of the sample was added to $2 \mathrm{~mL}$ sodium carbonate ( $2 \mathrm{~g}$ in $100 \mathrm{~mL}$ distilled water) for 2 mins at room temperature before mixing with FolinCiocalteu reagent. It was left for 30 mins before taking the reading at $750 \mathrm{~nm}$. The experiment was done in triplicate and the absorbance value was compared to the standard curve.

\section{$2.7 \alpha$-Amylase inhibitory activity assay}

Firstly, $500 \mu \mathrm{L}$ of each sample and $500 \mu \mathrm{L}$ of $0.02 \mathrm{M}$ phosphate buffer ( $\mathrm{pH}$ 6.9) containing porcine pancreatic $\alpha$-amylase (EC 3.2.1.1) $(0.5 \mathrm{mg} / \mathrm{mL})$ were incubated for 10 mins at room temperature. Next, $500 \mu \mathrm{L}$ of $1 \%$ starch solution in $0.02 \mathrm{M}$ phosphate buffer $(\mathrm{pH}$ 6.9) was incorporated in the mixture solution. Then, the solution was incubated for $10 \mathrm{mins}$ at room temperature before added with $1.0 \mathrm{~mL}$ of dinitrosalicylic acid (DNSA). Thereafter, the reaction in the solution was ceased by incubating it for $5 \mathrm{mins}$ in a $100^{\circ} \mathrm{C}$ water bath before it was let to cool to room temperature. About $10 \mathrm{~mL}$ of distilled water was added to dilute the reaction mixture before measuring the absorbance at $540 \mathrm{~nm}$
(Worthington, 1993). All other reagents and the enzyme without the test sample was referred as blank sample. The $\alpha$-amylase inhibitory activity was referred as percentage inhibition.

$$
\% \text { inhibition }=\left[\frac{(x-y)}{x}\right] \times 100
$$

Where $\mathrm{x}=$ the reference sample absorption value; and $\mathrm{y}$ $=$ the test sample absorption value.

\subsection{Statistical analysis}

The statistical analyses were done by a one-way ANOVA using IBM SPSS Statistics 20. The results were expressed as mean $\pm \mathrm{SD}$, to show variations in the various experimental conditions. Differences are considered significant when $p<0.05$.

\section{Results and discussion}

\subsection{DPPH radical scavenging assay}

Table 2 shows the results for the DPPH assay. Formulation with 100\% Trigona honey exhibits the highest scavenging activity with percentage of $90.09 \%$ followed by $F$. carica $(88.09 \%)$ and $F$. deltoidea $(81.93 \%)$. The antioxidant activity of the honey is attributed from its phenolic and flavonoids structure (Khalil et al., 2011; Muhammad, 2012). This is because Trigona honey has bioactive compounds such as polyphenols, organic acids, vitamins, glutathione peroxidase and catalase that aids in improving the antioxidative property (Aljadi and Kamaruddin, 2004). However, formulations that were combined with Trigona honey has an antagonistic interaction. These results correspond to a previous study which shows that interaction between flavonoid compounds can work either synergistically or antagonistically (Hidalgo et al., 2010). O. stamineus showed the least DPPH activity $(24.29 \%)$ as compared to other studied samples ( $F$. carica, $86.98 \% ; F$. deltoidea $82.93 \%$; Trigona honey, $90.09 \%)$. It might be due to the extraction process which was done under high temperature with prolonged time. The previous study showed extraction at higher temperatures and longer extraction time decreased the free radical-scavenging activity of $O$. stamineus extracts (Chew et al., 2011).

\subsection{FRAP assay}

Based on Table 3, the highest FRAP value was found from $100 \%$ O. stamineus and $100 \% F$. deltoidea (148.95 and $148.78 \mu \mathrm{g} / \mathrm{mL}$, respectively) with no significant difference $(p<0.05)$. Although formulation 6 , 7 and 9 showed synergistic interaction effect, the FRAP values are still lower significantly $(p<0.05)$ than the individual $O$. stamineus and $F$. deltoidea extract. In contrast to formulation 5 , indifferent interaction can be 
Table 2. DPPH scavenging activity in each formulation

\begin{tabular}{ccccc}
\hline No & Description & Predicted value & DPPH scavenging activity (\%) & Type of interaction \\
\hline 1 & $100 \% \mathrm{D}$ & - & $90.09 \pm 0.51^{\mathrm{a}}$ & - \\
2 & $100 \% \mathrm{~B}$ & - & $24.29 \pm 1.03^{\mathrm{i}}$ & - \\
3 & $100 \% \mathrm{~A}$ & - & $86.98 \pm 0.51^{\mathrm{b}}$ & - \\
4 & $100 \% \mathrm{C}$ & - & $82.93 \pm 1.02^{\mathrm{c}}$ & - \\
5 & $50 \% \mathrm{~A}+50 \% \mathrm{~B}$ & $56.19 \pm 0.44$ & $60.90 \pm 0.05^{\mathrm{e}}$ & Synergistic \\
6 & $50 \% \mathrm{~B}+50 \% \mathrm{D}$ & $57.19 \pm 0.46$ & $46.85 \pm 0.10^{\mathrm{g}}$ & Antagonistic \\
7 & $50 \% \mathrm{C}+50 \% \mathrm{D}$ & $86.01 \pm 0.53$ & $79.28 \pm 0.09^{\mathrm{d}}$ & Antagonistic \\
8 & $33.33 \% \mathrm{C}+33.33 \% \mathrm{~B}+33.33 \% \mathrm{D}$ & $65.44 \pm 0.48$ & $60.00 \pm 1.32^{\mathrm{e}}$ & Antagonistic \\
9 & $33.33 \% \mathrm{~A}+33.33 \% \mathrm{~B}+33.33 \% \mathrm{D}$ & $67.49 \pm 0.47$ & $57.09 \pm 0.55^{\mathrm{f}}$ & Antagonistic \\
10 & $12.5 \% \mathrm{~A}+12.5 \% \mathrm{C}+12.5 \% \mathrm{D}+62.5 \% \mathrm{~B}$ & $47.69 \pm 0.43$ & $40.01 \pm 1.33^{\mathrm{h}}$ & Antagonistic \\
\hline
\end{tabular}

(A) F. carica, (B) O. stamineus, (C) F. deltoidea, (D) Trigona honey. Different superscript within the column indicates significant differences $(p<0.05)$

Table 3. FRAP content in each formulation

\begin{tabular}{ccccc}
\hline No & Description & Predicted value & FRAP value $(\mu \mathrm{g} / \mathrm{mL})$ & Type of interaction \\
\hline 1 & $100 \% \mathrm{D}$ & - & $119.55 \pm 1.342^{\mathrm{f}}$ & - \\
2 & $100 \% \mathrm{~B}$ & - & $148.95 \pm 0.801^{\mathrm{a}}$ & - \\
3 & $100 \% \mathrm{~A}$ & - & $143.73 \pm 2.165^{\mathrm{c}}$ & - \\
4 & $100 \% \mathrm{C}$ & - & $148.78 \pm 0.394^{\mathrm{a}}$ & - \\
5 & $50 \% \mathrm{~A}+50 \% \mathrm{~B}$ & $143.99 \pm 1.40$ & $144.11 \pm 0.08^{\mathrm{bc}}$ & Indifferent \\
6 & $50 \% \mathrm{~B}+50 \% \mathrm{D}$ & $132.52 \pm 1.26$ & $136.46 \pm 0.68^{\mathrm{e}}$ & Synergistic \\
7 & $50 \% \mathrm{C}+50 \% \mathrm{D}$ & $131.51 \pm 1.09$ & $139.46 \pm 1.75^{\mathrm{de}}$ & Synergistic \\
8 & $33.33 \% \mathrm{C}+33.33 \% \mathrm{~B}+33.33 \% \mathrm{D}$ & $137.32 \pm 0.99$ & $145.18 \pm 1.52^{\mathrm{abc}}$ & Synergistic \\
9 & $33.33 \% \mathrm{~A}+33.33 \% \mathrm{~B}+33.33 \% \mathrm{D}$ & $134.69 \pm 1.51$ & $141.23 \pm 0.98^{\mathrm{cd}}$ & Synergistic \\
10 & $12.5 \% \mathrm{~A}+12.5 \% \mathrm{C}+12.5 \% \mathrm{D}+62.5 \% \mathrm{~B}$ & $143.35 \pm 1.02$ & $148.13 \pm 0.51^{\mathrm{ab}}$ & Synergistic \\
\hline
\end{tabular}

(A) F. carica, (B) O. stamineus, (C) F. deltoidea, (D) Trigona honey. Different superscript within the column indicates significant differences $(p<0.05)$

seen between the combination of the equal concentration of F. carica and $O$. stamineus. These phenomena are in accordance with reports by Hajimehdipoor et al. (2014) which indicates that when an individual extract is mixed, there is a risk of interfering and even neutralizing the antioxidant effects. In the case of the lowest FRAP value, $100 \%$ Trigona honey showed FRAP values of $119.55 \mu \mathrm{g} / \mathrm{mL}$. However, it is considered as relatively high FRAP content if compared to other types of honey due to the contributions of flavonoids and phenolic compounds to the antioxidative capacity of the honey (Alzahrani et al., 2012). Trigona honey yield lower FRAP value compared to other formulations because FRAP assay does not react immediately with some antioxidants compound such as glutathione found in honey (Guo et al., 2003).

\subsection{Total phenolic content (TPC)}

The highest TPC content would be a mixture of $50 \%$ $F$. carica $-50 \%$ O. stamineus and $50 \%$ O. stamineus $50 \%$ Trigona honey (Table 4). Notably, all formulation showed synergistic interaction effect for TPC content. This effect might be contributed from the positive interaction between phenolic compounds in each mixture of plant extract that attributed to their antioxidant activity (Muhammad et al., 2012; Widyawati et al., 2017; Rahim et al., 2019). Such phenolic compounds which are eupatorin, sinensetin, 3'-hydroxy-5,6,7,4'tetramethoxyflavone and rosmarinic acid, were reported contains in O. stamineus (Abdullah, 2012). While $F$. carica leaves contain phenolic acids such as oxalic, citric, malic, quinic, shikimic and fumaric acids (Oliveira et al., 2008). Other than that, Trigona honey main compounds are salicylic, p-coumaric acid, aromadendrin and taxifolin (Biluca et al., 2020). These findings also supported by Liu (2003) which reported that the synergistic effects of plant combinations may be due to the increased interaction possibilities which allowing more cooperative effects between compounds in the mixtures (Liu, 2003).

\section{$3.4 \alpha$-Amylase inhibitory activity assay}

Based on Table 5, highest $\alpha$-amylase percentage inhibition is exhibited by $F$. deltoidea $(8.826 \%)$. This is might be due to the presence of a more potent compound called vitexin, sitosterol and isovitexin which reported could inhibit $\alpha$-amylase enzyme (Joseph and Raj, 2011; Bakar et al., 2018). The ability of $F$. deltoidea in 
Table 4. TPC content in each formulation

\begin{tabular}{ccccc}
\hline No & Description & Predicted value & TPC value $(\mu \mathrm{g} / \mathrm{mL})$ & Type of interaction \\
\hline 1 & $100 \% \mathrm{D}$ & - & $24.84 \pm 2.16^{\mathrm{g}}$ & - \\
2 & $100 \% \mathrm{~B}$ & - & $132.71 \pm 0.56^{\mathrm{ab}}$ & - \\
3 & $100 \% \mathrm{~A}$ & - & $54.76 \pm 1.32^{\mathrm{f}}$ & - \\
4 & $100 \% \mathrm{C}$ & - & $82.63 \pm 2.26^{\mathrm{d}}$ & - \\
5 & $50 \% \mathrm{~A}+50 \% \mathrm{~B}$ & $91.87 \pm 0.65$ & $133.77 \pm 0.508^{\mathrm{a}}$ & Synergistic \\
6 & $50 \% \mathrm{~B}+50 \% \mathrm{D}$ & $83.11 \pm 0.87$ & $133.17 \pm 0.521^{\mathrm{a}}$ & Synergistic \\
7 & $50 \% \mathrm{C}+50 \% \mathrm{D}$ & $56.21 \pm 1.34$ & $60.24 \pm 0.289^{\mathrm{e}}$ & Synergistic \\
8 & $33.33 \% \mathrm{C}+33.33 \% \mathrm{~B}+33.33 \% \mathrm{D}$ & $81.71 \pm 1.08$ & $124.86 \pm 0.86^{\mathrm{c}}$ & Synergistic \\
9 & $33.33 \% \mathrm{~A}+33.33 \% \mathrm{~B}+33.33 \% \mathrm{D}$ & $72.41 \pm 0.83$ & $127.65 \pm 0.55^{\mathrm{c}}$ & Synergistic \\
10 & $12.5 \% \mathrm{~A}+12.5 \% \mathrm{C}+12.5 \% \mathrm{D}+62.5 \% \mathrm{~B}$ & $103.37 \pm 0.78$ & $128.29 \pm 2.81^{\mathrm{bc}}$ & Synergistic \\
\hline
\end{tabular}

(A) F. carica, (B) O. stamineus, (C) F. deltoidea, (D) Trigona honey. Different superscript within the column indicates significant differences $(p<0.05)$

Table 5. $\alpha$-Amylase percentage inhibition in each formulation

\begin{tabular}{ccccc}
\hline No & Description & Predicted value & $\alpha$-Amylase inhibition activity (\%) & Type of interaction \\
\hline 1 & $100 \% \mathrm{D}$ & - & $6.824 \pm 0.593^{\mathrm{c}}$ & - \\
2 & $100 \% \mathrm{~B}$ & - & $4.828 \pm 1.133^{\mathrm{e}}$ & - \\
3 & $100 \% \mathrm{~A}$ & - & $6.208 \pm 1.111^{\mathrm{bc}}$ & - \\
4 & $100 \% \mathrm{C}$ & - & $8.826 \pm 1.63^{\mathrm{a}}$ & - \\
5 & $50 \% \mathrm{~A}+50 \% \mathrm{~B}$ & $5.479 \pm 0.93$ & Synergistic \\
6 & $50 \% \mathrm{~B}+50 \% \mathrm{D}$ & $5.826 \pm 0.86$ & $5.22 \pm 1.56^{\mathrm{d}}$ & Indifferent \\
7 & $50 \% \mathrm{C}+50 \% \mathrm{D}$ & $7.825 \pm 1.11$ & $7.22 \pm 1.05^{\mathrm{cd}}$ & Indifferent \\
8 & $33.33 \% \mathrm{C}+33.33 \% \mathrm{~B}+33.33 \% \mathrm{D}$ & $6.826 \pm 1.12$ & $6.49 \pm 1.06^{\mathrm{bc}}$ & Indifferent \\
\hline
\end{tabular}

(A) F. carica, (B) O. stamineus, (C) F. deltoidea, (D) Trigona honey. Different superscript within the column indicates significant differences $(p<0.05)$

inhibiting $\alpha$-amylase enzyme also reported in another study conducted by Adam and his colleagues (2011). It was also found in this study formulation 5 which contains $50 \% F$. carica - $50 \%$ O. Stamineus gives synergistic interaction effect. However, its value of $\alpha$ amylase inhibitory activity is still lower than individual inhibition of $F$. deltoidea. Farsi et al., (2011) reported there was a direct correlation between antioxidant activity and $\alpha$-amylase inhibitory activity. Hence, it is concluded that the highest $\alpha$-amylase inhibitory activity of $F$. deltoidea may be contributed by its high antioxidant compounds.

\section{Conclusion}

In conclusion, formulation with $100 \%$ Trigona honey gives the highest DPPH free radical scavenging activity. While the formulation of $50 \% \mathrm{~F}$. carica $-50 \%$ $O$. stamineus and $50 \%$ O. stamineus - 50\% Trigona honey exhibits the highest TPC content. Other than that, the best formulation for the FRAP assay is $100 \% O$. stamineus and $100 \% F$. deltoidea. This indicates that these individual extracts and mixtures can be used to regulate free radicals. The highest percentage inhibition of the $\alpha$-amylase enzyme is achieved by individual formulation of $F$. deltoidea which exhibit high antioxidant activity hence it can be concluded that $\alpha$ - amylase inhibitory activity of $F$. deltoidea may be contributed by the antioxidant compounds. More indepth studies are required to isolate, classify and analyze the active ingredients of this plant for the management of diabetes.

\section{Conflict of interest}

Authors declare no conflict of interest.

\section{Acknowledgements}

The research was supported by the Ministry of Higher Education Malaysia through Fundamental Research Grant Scheme (FRGS/1/2017/WAB11/ UTHM/03/1) Vot No. 1646 and partially sponsored under Postgraduate Research Grant Scheme (GPPS) Vot. H291, funded by Universiti Tun Hussein Onn Malaysia (UTHM).

\section{References}

Abdullah, S., Shaari, A.R. and Azimi, A. (2012). Effect of drying methods on metabolites composition of misai kucing (Orthosiphon stamineus) leaves. Apcbee Procedia, 2, 178-182. https:// doi.org/10.1016/j.apcbee.2012.06.032 
Adam, Z., Hamid, M., Ismail, A. and Khamis, S. (2007). Effect of Ficus deltoidea aqueous extract on blood glucose level in normal and mild diabetic rats. Malaysian Journal of Health Sciences, 5(2), 916.

Adam, Z., Ismail, A., Khamis, S., Mokhtar, M.H.M. and Hamid, M. (2011). Antihyperglycemic activity of $F$. deltoidea ethanolic extract in normal rats. Sains Malaysiana, 40(5), 489-495.

Aljadi, A.M. and Kamaruddin, M.Y. (2004). Evaluation of the phenolic contents and antioxidant capacities of two Malaysian floral honeys, Food Chemistry, 85(4), 513-518. https://doi.org/10.1016/S0308-8146(02) 00596-4

Alzahrani, H.A., Alsabehi, R., Boukraâ, L., Abdellah, F., Bellik, Y. and Bakhotmah, B.A. (2012). Antibacterial and antioxidant potency of floral honeys from different botanical and geographical origins, Molecules, 17(9), 10540-10549. https:// doi.org/10.3390/molecules 170910540

Bakar, A.R.A., Manaharan, T., Merican, A.F. and Mohamad, S.B. (2018). Experimental and computational approaches to reveal the potential of Ficus deltoidea leaves extract as $\alpha$-amylase inhibitor. Natural Product Research, 32(4), 473-476. https:// doi.org/10.1080/14786419.2017.1312393

Benzie, I.F. and Strain, J.J. (1996). The ferric reducing ability of plasma (FRAP) as a measure of antioxidant power: the FRAP assay. Analytical Biochemistry, 239(1), 70-76. https://doi.org/10.1006/ abio.1996.0292

Biluca, F.C., da Silva, B., Caon, T., Mohr, E.T.B., Vieira, G.N., Gonzaga, L.V., Vitali, L., Micke G., Fett, R. Dalmarco, E.M. and Costa, A.C.O. (2020). Investigation of phenolic compounds, antioxidant and anti-inflammatory activities in stingless bee honey (Meliponinae). Food Research International, 129, 1-32. https://doi.org/10.1016/ j.foodres.2019.108756

Chew, K.K., Khoo, M.Z., Ng, S.Y., Thoo, Y.Y., Aida, W.W. and Ho, C.W. (2011). Effect of ethanol concentration, extraction time and extraction temperature on the recovery of phenolic compounds and antioxidant capacity of Orthosiphon stamineus extracts. International Food Research Journal, 18 (4), 1427.

du Toit, R., Volsteedt, Y. and Apostolides, Z. (2001). Comparison of the antioxidant content of fruits, vegetables and teas measured as vitamin $\mathrm{C}$ equivalents. Toxicology, 166(1-2), 63-69. https:// doi.org/10.1016/S0300-483X(01)00446-2

Facchini, F.S., Hua, N.W., Reaven, G.M. and Stoohs,
R.A. (2000). Hyperinsulinemia: the missing link among oxidative stress and age-related diseases? Free Radical Biology and Medicine, 29(12), 13021306. https://doi.org/10.1016/S0891-5849(00)00438$\mathrm{X}$

Farsi, E., Shafaei, A., Hor, S.Y., Ahamed, M.B.K., Yam, M.F., Attitalla, I.H., Asmawi, M.Z. and Ismail, Z. (2011). Correlation between enzymes inhibitory effects and antioxidant activities of standardized fractions of methanolic extract obtained from Ficus deltoidea leaves. African Journal of Biotechnology, 10(67), 15184-15194. https://doi.org/10.5897/ AJB1 1.1365

Guo, C., Yang, J., Wei, J., Li, Y., Xu, J. and Jiang, Y. (2003). Antioxidant activities of peel, pulp and seed fractions of common fruits as determined by FRAP assay. Nutrition Research, 23(12), 1719-1726. https://doi.org/10.1016/j.nutres.2003.08.005

Hajimehdipoor, H., Shahrestani, R. and Shekarchi, M. (2014). Investigating the synergistic antioxidant effects of some flavonoid and phenolic compounds. Research Journal of Pharmacognosy, 1(3), 35-40.

Hasham, R., Choi, H-K., Sarmidi, M.R. and Park, C-S., (2013). Protective effects of a Ficus deltoidea (Mas cotek) extract against UVB-induced photoageing in skin cells. Biotechnology and Bioprocess Engineering, 18(1), 185-193. https:// doi.org/10.1007/s12257-012-0353-2

Hidalgo, M., Sánchez-Moreno, C. and de PascualTeresa, S. (2010). Flavonoid-flavonoid interaction and its effect on their antioxidant activity. Food Chemistry, 121(3), 691-696. https://doi.org/10.1016/ j.foodchem.2009.12.097

Joseph, B. and Raj, S.J. (2011). Pharmacognostic and phytochemical properties of Ficus carica Linn-An overview. International Journal of Pharmtech Research, 3(1), 8-12.

Kelble, A. (2005). Spices and type 2 diabetes. Nutrition and Food Science, 35(2), 81-87. https:// doi.org/10.1108/00346650510585868

Khalil, M.I., Alam, N., Moniruzzaman, M., Sulaiman, S.A. and Gan, S.H. (2011). Phenolic acid composition and antioxidant properties of Malaysian honeys. Journal of Food Science, 76(6), 921-928. https://doi.org/10.1111/j.1750-3841.2011.02282.x

Liu, R.H. (2003). Health benefits of fruit and vegetables are from additive and synergistic combinations of phytochemicals. The American Journal of Clinical Nutrition, 78(3), 517-520. https://doi.org/10.1093/ ajcn/78.3.517S

Malviya, N., Jain, S. and Malviya, S. (2010). Antidiabetic potential of medicinal plants. Acta 
Poloniae Pharmaceutica - Drug Research, 67(2), 113-118.

Mansor, C.N.A.N.C., Latip, J. and Markom, M. (2016). Preparation of Orthosiphon stamineus enrichedextracts and evaluation of their free radical scavenging activity. AIP Conference Proceedings, 1784(1), 1-5. https://doi.org/10.1063/1.4966751

Marwat, S.K., Khan, M.A., Khan, M.A., Akbari, A.H., Ahmad, M., Zafar, M. and Ahmad, F. (2011). Medicinal and pharmacological potentiality of the plant at-tin-common Fig (Ficus carica L.). Asian Journal of Chemistry, 23(1), 1.

McCune, L.M. and Johns, T. (2002). Antioxidant activity in medicinal plants associated with the symptoms of diabetes mellitus used by the indigenous peoples of the North American boreal forest. Journal of Ethnopharmacology, 82(2-3), 197-205. https:// doi.org/10.1016/S0378-8741(02)00180-0

Miliauskas, G., Venskutonis, P.R. and Van Beek, T.A. (2004). Screening of radical scavenging activity of some medicinal and aromatic plant extracts. Food Chemistry, 85(2), 231-237. https://doi.org/10.1016/ j.foodchem.2003.05.007

Muhammad, N., Din, L.B., Sahidin, I., Hashim, S.F., Ibrahim, N., Zakaria, Z. and Yaacob, W.A. (2012). Acuminatol and other antioxidative resveratrol oligomers from the stem bark of Shorea acuminata. Molecules, 17(8), 9043-9055. https:// doi.org/10.3390/molecules 17089043

Oliveira, A.P., Pereira, J.A., Andrade, P.B., Valentão, P., Seabra, R.M. and Silva, B.M. (2008). Organic acids composition of Cydonia oblonga Miller leaf. Food Chemistry, 111(2), 393-399. https://doi.org/10.1016/ j.foodchem.2008.04.004

Palafox-Carlos, H., Gil-Chávez, J., Sotelo-Mundo, R.R., Namiesnik, J., Gorinstein, S. and González-Aguilar, G.A. (2012). Antioxidant interactions between major phenolic compounds found in 'Ataulfo' mango pulp: chlorogenic, gallic, protocatechuic and vanillic acids. Molecules, 17(11), 12657-12664. https:// doi.org/10.3390/molecules171112657

Rahim, N.F.A., Muhammad, N., Putra, T.N.M.T., Nur, W., Rashidi, A.S.W.M., Abdullah, N., Balkis A. Talip, Abu, M.F. and Gul, M.T. Antioxidant activity and its interaction effect on polyherbal formulations of Nephrodium inophyllum, Polygonum minus Annona squamosal L. and Stevia rebaudiana. Journal of Advanced Research in Fluid Mechanics and Thermal Sciences, 61(1), 1-9

Rashidi, W.N.A.S.W.M., Muhammad, N., Sairi, N.H., Rahim, N.F.A., Talip, B.A., Abdullah, N. and Bakar, M.F.A. (2019). Phytochemical Analysis and In-Vitro
Antiurolithiatic Properties of Selected Malaysian Herbs. Journal of Advanced Research in Fluid Mechanics and Thermal Sciences, 64(1), 152-159

Thompson, K.H. and Godin, D.V. (1995). Micronutrients and antioxidants in the progression of diabetes. Nutrition Research, 15(9), 1377-1410. https:// doi.org/10.1016/0271-5317(95)02012-K

Vongsak, B., Sithisarn, P., Mangmool, S., Thongpraditchote, S., Wongkrajang, Y. and Gritsanapan, W. (2013). Maximizing total phenolics, total flavonoids contents and antioxidant activity of Moringa oleifera leaf extract by the appropriate extraction method. Industrial Crops and Products, 44, 566-571. https://doi.org/10.1016/ j.indcrop.2012.09.021

Widyawati, P.S., Werdani, Y.D.W., Setiokusumo, C. and Kartikasari, A. (2017). In Vitro Antioxidant Capacities and Antidiabetic Properties of Pluchea Leaves and Green Tea Mixtures at Various Proportions. International Journal of Pharmacy and Pharmaceutical Sciences, 9(8), 203-208. https:// doi.org/10.22159/ijpps.2017v9i8.19545

Worthington, V. (1993). Alpha amylase Worthington enzyme manual, p. 36-41. Freehold, New Jersey, USA: Worthington Biochemical Corporation.

Yazan, L.S., Zali, M., Shyfiq, M.F., Mohd Ali, R., Zainal, N.A., Esa, N., Sapuan, S., Ong, Y.S., Tor, Y.S., Gopalsamy, B. and Voon, F.L. (2016). Chemopreventive properties and toxicity of Kelulut honey in Sprague Dawley rats induced with Azoxymethane. BioMed Research International, 2016, 403926. https://doi.org/10.1155/2016/4036926 